\title{
Forest Engineering Research in Canada
}

\author{
by
}

\author{
Jean A. Bérard
}

\section{Introduction}

In the history of Canadian forest research, August 31, 1974 , marked an important event - the incorporation of a national institute dedicated to forest engineering research and development activities. The formation of the Forest Engineering Research Institute of Canada (FERIC) was not the product of some vague spontaneous generation process, but rather the evolutionary consequence of many years of encounters between people and situations during the pioneering days of forestry and logging in our country.

Though this article is about the current status of forest engineering research in Canada, and more specifically about the Forest Engineering Research Institute of Canada, it is only fitting to begin with a review of how the people-situation encounters gradually became the basis of institutionalized forest engineering research as it exists today.

\section{Early Forest Engineering Research in Western Canada}

The first formal logging research conducted in the Pacific Northwest consisted of productivity studies of steam yarders by Axle Branstrom of the University of Washington in the 1930's. These studies were sponsored by the Pacific Logging Congress, an association of American and Canadian loggers. Branstrom's assistant on this project was John Liersch, a Canadian, who later became head of the Forestry Department at the University of British Columbia. During the Second World War, he acted as a consultant to the federal government and logging companies to expedite the production of Sitka spruce for the aircraft industry. While at UBC, Liersch inspired students in the use of applied research on forestry operations.

In 1932, J.H. Jenkins and F.W. Gurnsey of the Western Forest Products Laboratory began to measure wood waste left after logging. Comox Logging Ltd., the Powell River Company, and the Forest Products Laboratory cooperated in an experiment in 1937 to re-log cutover areas for pulpwood. This "Ladysmith Experiment" showed that 19\% of the total volume of the merchantable volume in the stand was unsuitable for lumber, but suitable for pulp. It was featured in the 1945 report of the Commissioner, the Hon. Gordon McG. Sloan relating to the B.C. forest resources and also

JJohn Hemmingson, Jack McKercher, Keith Gill, Vern Wellburn, Roger Manning, Ken Williams. contributed to the expansion of the pulp and paper industry in that province after the war.

In 1938, Jack Challenger of Bloedel Stuart and Welsh, headed a small group of Canadian companies to import experimental chain saws from Germany. These saws performed well enough to prove the concept. Because of the Second World War, industrial communications with Germany ceased and all the research and development necessary to modify the chain saw into a useful logging tool took place in the Pacific Northwest of the United States and in British Columbia.

In the late 1940's and 1950's, several large forest companies employed forest engineers to inventory the volume of timber in their holdings that would be suitable for the manufacture of pulp and paper. They also conducted trials and experiments to determine the most efficient way to harvest smaller, less uniform trees and logs. Many of the senior executives still employed by or recently retired from the forest industry worked on these studies. ${ }^{1}$

Logging Research at the Western Forest Products Laboratory continued until 1975, but it was never expanded beyond two or three people.

The coast industry converted from railroad logging to truck logging during the late 1940's and 1950's. Truck and trailer manufacturers (Hayes, Pacific, and Kenworth) developed specialty trucks for hauling logs and improved truck brakes. Also at that time, mobile radios were introduced into the woods. No formal forest engineering research organization existed then, and the regular activities of these developments were coordinated by the BC Loggers Association and the Pacific Logging Congress.

During the 1950's, power shovels were converted to log loaders. This change improved the overall material handling efficiency by separating yarding from loading. Washington Ironworks and Skagit Inc., developed and manufactured machines for log loading. These same companies, as well as the Berger Company and S. Madill, began to manufacture steel spars in the late 1950's. Most of the development took place in cooperation between company and manufacturer.

At about the same time, Le Tourneau Inc., Wagner Corp., and Kenworth introduced wheeled skidders to extend the reach of crawler tractors for skidding logs. These machines 
had a rigid frame and were not articulated. Ironically, by the time the articulated rubber-tired skidder was perfected in eastern Canada and built large enough for coastal conditions, this logging system was almost completely eliminated in western Canada because of environmental damage.

Power shovels used to build railroad grades were replaced by bulldozers to build truck roads. Developments and improvements in bulldozers, blades, and winches, and also the development of mobile rock drilis, greatly changed coastal logging. Instead of a few well-spaced railroads and long-distance yarders, the system changed to a complex network of closely spaced truck roads and short-distance yarders

The development of log-carrying barges had a major impact on the forest industry because it made accessible the timber in every small, isolated inlets on the Northern Coast, the west coast of Vancouver Island, and the Queen Charlottes. Large Davis and Gibson rafts were used to transport logs over long distances through rough water in the 1940 's. Construction of these rafts required an expensive shore-based facility and raft towing was slow. Large volumes of valuable timber were required to justify the expense and log losses from marine borers was high. The Gibson Brothers experimented with ships to transport spruce logs for the wartime aircraft industry. These ships assured adequate protection of the logs, but were difficult to load and unload; the idea was so successful that it led to the manufacture of selfdumping barges by local shipyards. In 1960, BC Forest Products mounted cranes on a barge to eliminate the shorebased loading facility. Later, MacMillan Bloedel constructed two self-propelled, self-loading, self-dumping log ships. Once again, all of this development took place through informal cooperation between forest companies, towing companies, and shipyards.

In the late 1950's, Le Tourneau Inc. developed large front-end loaders or stackers for sorting red-wood logs in California. BC Forest Products Ltd. introduced this system to Canada in 1959 when they built the first dryland sortyard at Sooke, B.C.

During the period 1930 to 1960 , the forest industry of interior B.C. had been based primarily on railway ties. The mills were located in the forest with timber skidded directly to the mill with horses, skidders, and arch trucks. When distances became too long, the mill was moved. This approach was unsuitable for supplying large permanent sawmills and, in the early 1970's, a group of logging managers in Prince George formed a group to investigate new logging methods. This group was spear-headed by Doug Little and Mac McLaggan of Northwood Pulp and Timber and, following studies of operations in eastern Canada, concluded that the $\mathrm{BC}$ interior forest industry had more in common with Ontario and Quebec than with coastal B.C. Some of the people became active in the Woodlands Division of CPPA and they participated in the establishment of a national institute for the conduct of forest engineering research, FERIC.

\section{Early Forest Engineering in Eastern Canada}

During the 60 years of pioneering developments on forest operations in western Canada, forest engineering research was proceeding on a parallel course in eastern Canada.
Alexander Koroleff is a familiar name in Canadian forestry. A graduate of the Imperial Forestry Academy in St. Petersburg (now Leningrad), Koroleff came to the U.S.A. in 1919, obtained a M.F. degree from Yale in 1922 and became the Manager of the Woodlands Section, Canadian Pulp and Paper Association, in 1927. Under his direction, studies were undertaken on floatability and sinkage of pulpwood, the use of trucks and tractors, and power saws, etc., but his major contribution to the industry was undoubtedly the introduction of a disciplined approach to the investigation of woodlands operations and related problems.

Another pioneer in forest engineering research was W. $\mathrm{Ab}$-Yberg, remembered for his "Introduction of Production Standards Into the Preparation of Logging Cost" while employed by the Canadian International Paper Company.

On the equipment front, the concept of articulated rubber-tired skidders was introduced by B.J. McColl and developed through the cooperation of equipment manufacturers and the forest industry. Along with the power saw and the roadside slasher, the skidder became the pivotal element of the tree-length system which dominated the wood harvesting operations in eastern Canada for more than 25 years. During that period, multi-function machines like the Vit FellerBuncher, Beloit Harvester, Koehring Shortwood Harvester, LRA Arbomatik, etc. were introduced to forestry operations but met with varying degrees of success primarily because the forest "milieu" was not technologically ready.

In 1962, three companies, Canadian International Paper Company, Ontario Paper Company and Abitibi Paper Company formed a consortium for the purpose of developing a full tree harvesting system that included a feller-skidder teamed with a processor at roadside landing. This consortium, headed by Douglas Hamilton, adopted and successfully exploited a systematized approach to equipment development, as advocated earlier by Alex Koroleff, B.J. McColl and W.A.E. Pepler. The key factors in this success were undoubtedly a clear definition of the concept to be developed based on a comprehensive analysis of the stand and environmental conditions in which the proposed system was to operate, sound project management and adequate funding. After 15 years of equipment development activities, Logging Research Associates was disbanded, but it had certainly paved the way for those who were to follow in the field of forest engineering research.

Institutionalized forest engineering research during the pioneering days was based at the Woodlands Research Division of the Pulp and Paper Research Institute of Canada and at the Logging Development Program of the Canadian Forestry Service. In 1975, these two organizations were united into the Forest Engineering Research Institute of Canada.

Many lessons were learned during those 60 pioneering years, and their impact, both favorable and unfavorable will be felt for many years. It may be concluded that considering the severe handicap under which the pioneer researchers in forest engineering worked, their legacy is a tribute to their tenacity, vision, and analytical perception of problems.

\section{Forest Engineering Research Today}

With the formation of FERIC in 1974, forest engineering research in Canada found a permanent home. Its mission is to be a leader in improving the economic productivity, environmental acceptance, and human factors of Canadian forestry 
and logging operations by developing innovative concepts, systems, and techniques and by stimulating cooperation between the forest industry, government agencies, machinery manufacturers, universities, and others involved in wood harvesting and tree growing operations.

\section{Work Program}

The work program, regularly reviewed by advisory committees, includes four major areas of activity:

\section{(a) Harvesting}

The extraction and processing of trees that may also include spur-road engineering and construction. FERIC's research in this area concentrates on machine and system evaluation and trials; machine improvement and development; wood recovery and utilization studies; and ergonomic and environmental studies.

\section{(b) Secondary Transportation}

This activity includes truck and water transportation, log sorting and allocation, and main-road construction and maintenance. Research includes: studies and developments of trucks and trailers to maximize payloads and improve efficiency; participation on committees with the Department of Highways to review regulations; truck and road relationship studies; road-construction and maintenance-equipment evaluations; evaluations of sortyard machines and systems; watertransport methods; and equipment evaluations.

\section{(c) Silvicultural Operations}

Includes research to improve the efficiency of methods and machines used for site preparation, tree planting, tree spacing, stand tending, pruning, and commercial thinning. Though the biological aspects of these operations are not included in FERIC's mandate, they are nevertheless considered in all silviculture related projects, and referred to specialists within universities and government research agencies or handled through joint projects

\section{(d) Woodlot Technology}

Research in this area is currently conducted by the Eastern Division. It includes studies and developments to improve the harvesting and forest management of woodlots and ownerships where the volume of wood or the area is too small to justify the purchase or employment of large expensive machines, and where machines must be modified to suit local conditions. These woodlots are, and will continue to be, an important source of wood to some member companies.

These four areas of activity, each headed by a group supervisor, constitute the "field research" units at FERIC. This is in keeping with the direction given FERIC at the time of its formation - to be iniensely field-oriented, yet imaginative.

Three support groups assist the field research units:

\section{(a) Design Engineering}

The Engineering and Design group is involved in concept analysis, general and detail drawings, supervision of the fabrication and assembly of prototypes and test equipment for ail of the four areas of field activity. One of the major roles is to propose and assess new concepts by interacting with the researchers of these areas.
The group is also responsible for two specific research/support activities, namely ergonomic/safety and maintenance. The latter activity was formerly conducted intermittently within various group levels as needed, but is currently coordinated within the Design Engineering group.

\section{(b) Instrumentation and Computers}

This support unit is responsible for evaluating, acquiring, maintaining, and supporting all instrumentation and computer resources required by both the research and administration activities; and to make recommendations as to the areas of potential improvement. The current computer facilities are dedicated $50 \%$ to research, $25 \%$ to accounting and word processing, and $25 \%$ to various databases.

\section{(c) Library}

The Library is a support unit responsible for providing information services to meet the requirements of FERIC's research program. In addition to assisting both research and head office staff within FERIC, the Library also services the information needs of FERIC's members in all areas related to FERIC's mandate.

\section{Personnel Resources}

In 1990, FERIC's personnel includes:

Management and administration

Researchers

Technicians

Clerical

$\frac{14}{84}$

Total

Occasionally, the Institute retains the services of consultants for specialized skills not available in-house.

The Head Office, located in Montreal, has a staff of 6 and the 80 other employees are divided equally between the Western Division (Vancouver) and the Eastern Division (Montreal).

\section{Budget}

The 1990 budget is as follows:

\begin{tabular}{lr} 
Revenue & $\frac{\$ 000 ' s}{2948}$ \\
\hline Member companies & 2365 \\
Government of Canada & 691 \\
Provinces & 1019 \\
Contracts \& other & $\overline{7023}$ \\
Total &
\end{tabular}

\section{Expenditures}

Harvesting

Secondary transportation

Silvicultural operations

1714

Woodlot engineering technology 540

Total (operating)

6650

Capital expenditures

A recent analysis indicates that considering the harvest/research ratio, FERIC resources do not compare favorably with those of its counterparts in the industrial world. 
Table 1. Forest Engineering Research in the World (May 1989)

\begin{tabular}{|c|c|c|c|c|}
\hline & $\begin{array}{l}\text { FERIC } \\
\text { (Canada) }\end{array}$ & $\begin{array}{l}\text { Skogsarbeten } \\
\text { (Sweden) }\end{array}$ & $\begin{array}{l}\text { Metsäteho } \\
\text { (Finland) }\end{array}$ & $\begin{array}{c}\text { LIRA } \\
\text { (New Zealand) }\end{array}$ \\
\hline \multicolumn{5}{|l|}{ Staff } \\
\hline Researchers & 48 & 40 & 20 & 9 \\
\hline Technicians & 10 & & 9 & \\
\hline Others & 21 & 25 & 7 & 6 \\
\hline Total & 79 & 65 & 36 & 15 \\
\hline $\begin{array}{l}\text { Annual Budget } \\
\text { (in million Cdn. \$) }\end{array}$ & 6 & 4.36 & 1.99 & 0.59 \\
\hline $\begin{array}{l}\text { Funding } \\
\text { Industry } \\
\text { Governments } \\
\text { Grants \& Contracts }\end{array}$ & $\begin{array}{l}45 \% \\
36 \% \\
19 \%\end{array}$ & $\begin{array}{l}37 \% \\
39 \% \\
24 \%\end{array}$ & $\begin{array}{r}98 \% \\
2 \% \\
-\end{array}$ & $\begin{array}{r}60 \% \\
32 \% \\
8 \%\end{array}$ \\
\hline $\begin{array}{l}\text { Annual Wood Harvest } \\
\text { (in million } \mathrm{m}^{3} \text { ) }\end{array}$ & 160 & 60 & 50 & 9 \\
\hline $\begin{array}{l}\text { Cost per } m^{3} \text { harvested } \\
\text { (in Cdn. \$) }\end{array}$ & 0.0375 & 0.0726 & 0.0398 & 0.0656 \\
\hline
\end{tabular}

The strategic scenario covering the $1990-94$ period, if fully implemented, will bring the level of FERIC's resources and activities in balance with the level of expected services.

\section{Cooperative Research}

FERIC has become the focal point of forest engineering research in Canada but it shares this distinction with many partners which include member companies, government research agencies, universities, and equipment manufacturers. As a matter of policy, FERIC seldom contracts out research. Rather, through cooperative research, the Institute has been most successful in working with people and organizations interested in the general and specific objectives of its work program. Thus, the pooling of skills and resources optimizes the return on investment of scarce research dollars.

Cooperative research has produced innovative technology successfully commercialized by Canadian equipment manufacturers and widely used on Canadian forestry operations. Notable developments include low-pressure, highfloatation tires to improve the off-road mobility of forest machines and reduce excessive damage to soil and natural regeneration; the application of circular saw technology to tree felling operations; and reliable radio warning system for forest workers in emergency situations.

The strength of FERIC in developing better or innovative technology for forestry operations stems from the regular presence of its field units on those operations; from the frequent face to face contacts with the operating personnel; and from the availability of performance, productivity and cost data gained from machine and systems evaluation studies. Thus, FERIC provides the basic data that was missing in the pioneering days to guide the equipment manufacturers in the design and development of technology for forestry. The forest is truly FERIC's laboratory and one of the Institute's major roles is to be the bridge between manufacturers and users of equipment.

On the academic front, FERIC's cooperative research reaches out to universities and more specifically to their faculties of forestry and is implemented in varied ways including post-graduate training, joint projects, summer student employment and their involvement in FERIC projects. For instance, seven under-graduates employed by FERIC have obtained Masters' degrees through joint FERIC university projects.
Recently, FERIC presented a brief to the seven Canadian university forestry schools aimed at strengthening their relations toward enhanced mutual benefits specifically in the areas of graduate training in forest engineering research, effective collaboration of faculty members in joint or contract projects, and opportunities for FERIC staff in post-graduate work.

Cooperative research at FERIC also extends to the international scene. The Institute maintains exchange programs (information, research results and personnel) with its counterparts in other countries such as Sweden, Finland, Australia and New-Zealand. It also provides training stages to researchers from other countries, e.g. China, Turkey, Hungary, Czechoslovakia, and Chile. These stages vary from a few months to a year.

\section{Conclusion}

For many years, forest engineering research in Canada was carried out in an ad hoc, un-structured manner. Like an orphan searching for parents and a home, it followed a meandering course. This quest ended in 1974 with the incorporation of FERIC.

During its first 15 years, FERIC has performed to expectations and established productive relationships with its research partners, within and outside Canada. Through the development of cooperative research, FERIC now has a base for involving all interested organizations in Canada-wide forest engineering research and development activities.

With Paprican and Forintek and FERIC, the network of government research centres, university research departments, private research laboratories and equipment manufacturers' $R$ \& D departments, the forest sector is well-equipped to meet the challenges and seize the opportunities arising from a rapidly changing world. Forestry is not immune to the upheavals that have marked our lives in the recent years. The effects of these disturbances will be long-lasting, particularly in forestry and in the future, FERIC in the pursuit of its research objectives will have to take into account the problems identified in four major trends:

(a) Public concern about the environment is a worldwide phenomenon that will increase and affect all forest activities, particularly logging. 
(b) Harvesting and silviculture will become more integrated as provincial governments shift more of the responsibility for the overall operations to the industry.

(c) The long-term wood supply is a concern in some mills but alternative fibre supplies (i.e., aspen, recycled fibres) will become increasingly important to the Canadian forest industry.

(d) The industry must improve safety, quality of work, and living conditions to attract a productive, stable work force.

\title{
Les Ressources en bois du Canada Conférence nationale
}

\author{
Du 3 au 6 juin 1990, Conference Centre, Victoria (Colombie-Britannique)
}

De nombreux conférenciers de tout le Canada parleront de l'état actuel des forêts canadiennes, des changements qui les affectent et de l'approvisionnement en bois à long terme.

Des présentations techniques porteront sur des études de cas et sur des façons innovatrices de calculer l'accroissement et le rendement, de formuler la réglementation forestière, d'assurer l'aménagement intégré de la ressource et de prévoir l'approvisionnement en bois.

Pour obtenir des renseignements sur l'inscription, le programme de la conférence, la séance d'affichage, le logement ou le transport, veuillez communiquer avec la personne suivante :

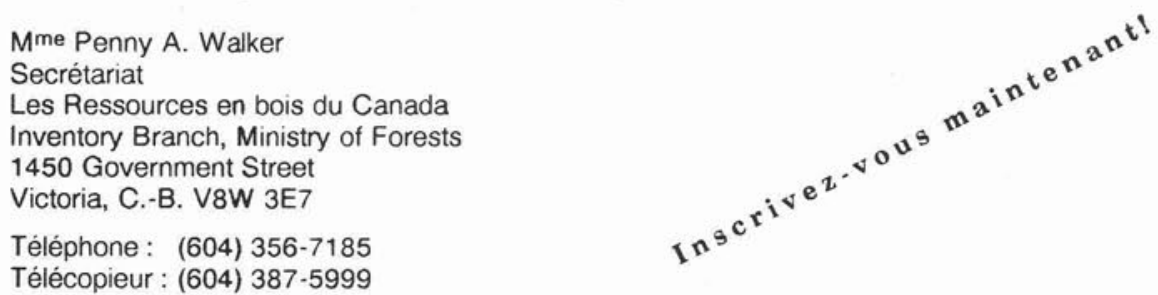

Parrainée par Forêts Canada et le ministère des Forêts de la Colombie-Britannique.

$\begin{array}{ll}\text { Forêts } & \text { Forestry } \\ \text { Canada } & \text { Canada }\end{array}$

\section{Environmental Auditing Symposium}

May $29-30,1990$ at the Ottawa Congress Centre

A forum on policies, techniques and trends presented by leading practitioners

Recommended for

- professionals in the chemical, mining, forestry, petroleum and manufacturing industries

- environmental engineers and managers

- auditing consultants

- municipal governments

- provincial and federal agencies responsible

for environmental protection

For further information, contact:

Peter Hunt, Program Coordinator

The Banff Centre for Management

Box 1020, Banff, Alberta, TOL 0C0

Tel: (403) 762-6327 Fax: (403) 762-6422

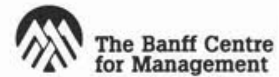

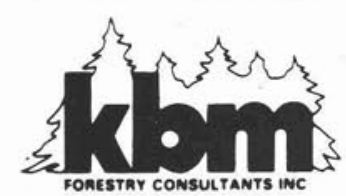

360 mooney street

thunder bay, ontario P7B 5R4

FOREST RESOURCE

- Inventory, Surveys and Evaluations

REFORESTATION EQUIPMENT

- Sales Service Parts Repair

REGENERATION \& SITE PREPARATION

- Contract Assessment Consulting

Tele 807-344-0811 Fax 807-345-3440

Toll free 1-800-465-3001 